\title{
Effect of different cleaning regimens on the adhesion of resin to saliva-contaminated ceramics
}

\begin{abstract}
Aladağ, Akın ; Elter, Bahar ; Çömlekoğlu, Erhan ; Kanat, Burcu ; Sonugelen, Mehmet ; Kesercioğlu, Atilla ;
\end{abstract}
Özcan, Mutlu

\begin{abstract}
PURPOSE: The aim of this study was to evaluate the influence of different cleaning regimens on the microshear bond strength ( $\mu \mathrm{SBS})$ of three different all-ceramic surfaces after saliva contamination. MATERIAL AND METHODS: Cubic ceramic specimens $(3 \times 3 \times 3 \mathrm{~mm}(3))$ were prepared from three types of ceramics: zirconium dioxide (Z), leucite-reinforced glass ceramic (E), lithium disilicate glass ceramic (EX; $n=12$ subgroup). A total of 144 composite resin cylinders (diameter: $1 \mathrm{~mm}$, height: $3 \mathrm{~mm}$ ) were prepared. Three human-saliva-contaminated surfaces of ceramic specimens were cleaned with either water spray (WS), with $0.5 \%$ sodium hypochlorite solution $(\mathrm{HC})$, or with a cleaning paste $(\mathrm{CP})$. Control surface $(\mathrm{C})$ was not contaminated or cleaned. Composite cylinders were bonded to each surface with a resin luting cement. All specimens were stored at $37^{\circ} \mathrm{C}$ in deionized water until fracture testing. $\mu$ SBS tests were performed in a universal testing machine $(0.5 \mathrm{~mm} / \mathrm{min})$, and the results $(\mathrm{MPa} \pm \mathrm{SD})$ were statistically analyzed (two-way ANOVA, Bonferroni a $=0.05)$. Fractured surfaces were analyzed to identify the failure types using an optical microscope at $50 \times$ magnification. Two representative specimens from all groups were examined with scanning electron microscopy. RESULTS: $\mu$ SBS test results were significantly affected by the saliva cleaning regimens $(\mathrm{p}=0.01)$ and the ceramic types $(\mathrm{p}=0.03)$. The interaction terms between the ceramic type and saliva cleaning regimen were also significant $(\mathrm{p}<0.05)$. There were no significant differences among the $\mu S B S$ values $(\mathrm{MPa} \pm \mathrm{SD})$ for the $\mathrm{Z}$ group $(\mathrm{C}=17.5 \pm 8.8$; $\mathrm{WS}=16.0 \pm 4.9 ; \mathrm{HC}=17.6$ $\pm 5.8 ; \mathrm{CP}=16.6 \pm 7.5 ; \mathrm{p}>0.05)$. In the EX group, $\mathrm{C}$ resulted in significantly higher $\mu \mathrm{SBS}$ values $(32.6 \pm 7.4)$ than $\mathrm{CP}(17.4 \pm 8.9)$, WS $(15.6 \pm 7.3)$, and HC $(14.3 \pm 4.5)(\mathrm{p}<0.05)$; however, $\mathrm{C}(20.4 \pm 7.1)$ and HC $(19.2 \pm 7.5)$ showed higher $\mu$ SBS values than CP $(13.8 \pm 4.8)$ and WS $(10.9 \pm 5.7)$ in the E group. Some cohesive failures within the luting resin were observed in the E and EX groups, whereas only adhesive failures were seen in zirconia groups for all surface treatments. CONCLUSIONS: Different ceramic surface cleaning regimens after saliva contamination of the zirconium dioxide revealed $\mu \mathrm{SBS}$ similar to the control group, whereas all surface cleaning regimens tested significantly decreased the bond strength values in the lithium disilicate glass ceramic. The leucite-reinforced glass-ceramic group benefited from $0.5 \%$ sodium hypochlorite solution cleaning with increased bond strengths. CLINICAL SIGNIFICANCE: Adhesive cementation of zirconia presents a clinically challenging protocol, and the cementation surface contamination of the zirconia restorations and the inadequate removal of the contaminants increase the risk of failure, as for all ceramic types. This study demonstrated that surface cleaning regimens should be applied according to different ceramic properties.
\end{abstract}

DOI: https://doi.org/10.1111/jopr.12170

Posted at the Zurich Open Repository and Archive, University of Zurich

ZORA URL: https://doi.org/10.5167/uzh-118978

Journal Article

Accepted Version 
Originally published at:

Aladağ, Akın; Elter, Bahar; Çömlekoğlu, Erhan; Kanat, Burcu; Sonugelen, Mehmet; Kesercioğlu, Atilla; Özcan, Mutlu (2015). Effect of different cleaning regimens on the adhesion of resin to saliva-contaminated ceramics. Journal of Prosthodontics, 24(2):136-145.

DOI: https://doi.org/10.1111/jopr.12170 


\section{EFFECT OF CLEANING METHODS ON BONDING TO SALIVA- CONTAMINATED CERAMICS}

\footnotetext{
${ }^{a}$ Akın ALADAĞ, DDS, PhD, Assistant Professor

${ }^{a}$ Bahar ELTER, DDS, PhD student

${ }^{a}$ Erhan ÇÖMLEKOĞLU, DDS, PhD, Associate Professor

${ }^{a}$ Burcu KANAT, DDS, PhD student

${ }^{\mathrm{b}}$ Mutlu ÖZCAN, DDS, PhD, Professor

a Ege University Faculty of Dentistry Department of Prosthodontics, Izmir, Türkiye

${ }^{\mathrm{b}}$ University of Zurich, Dental Materials Unit, Center for Dental and Oral Medicine, Clinic for Fixed and Removable Prosthodontics and Dental Materials Science, Zürich, Switzerland
}

\section{Corresponding Author:}

Dr. Akın ALADAĞ

Ege University, School of Dentistry

Department of Prosthodontics,

Bornova 35100-Izmir, Türkiye

Tel: $+90-232-3880327$

Fax: $+90-232-3880325$

E-mail:aladag.a@gmail.com

Key Words: Ceramics, saliva, bond strength, cleaning methods 


\section{ABSTRACT}

Purpose: To evaluate the influence of different cleaning methods on shear bond strength (SBS) of 3 different all ceramic surfaces after saliva contamination. Materials and Methods: Cubic ceramic specimens $(3 \times 3 \times 3 \mathrm{~mm})$ were prepared from three types of ceramics: Zirconiumdioxide (IPS e.max ZirCAD) (Z), IPSEmpress (IvoclarVivadent) (E), IPSe.max CAD (IvoclarVivadent) (EX) ( $n=10 /$ subgroup) and surface conditioned according to the ceramic type. A total of 120 composite-resin (TetricCeram,IvoclarVivadent) cylinders (diameter: $1 \mathrm{~mm}$,height:3mm) were prepared. Three human saliva contaminated surfaces of ceramic specimens were either cleaned with water spray (S1), with $0.5 \%$ sodium hypochlorite solution (S2) or with a cleaning paste (Ivoclean,IvoclarVivadent) (S3). Control surface (C) was not contaminated or cleaned. Composite cylinders were bonded to each surface with a luting resin cement (Variolink II, IvoclarVivadent). All specimens were stored at $37^{\circ} \mathrm{C}$ in deionized water until fracture. SBS tests were performed in a universal testing machine (Shimadzu, Japan, 0,5mm/min) and the results $(\mathrm{MPa} \pm \mathrm{SD})$ were statistically analyzed (ANOVA, Bonferroni $\alpha=0.05$ ). Fractured surfaces were examined with scanning electron microscopy (JEOL JSM-5200, Japan). Results: Mean SBS values for E were observed as $\mathrm{C}: 14,9 \pm 6, \mathrm{~S} 1: 12,1 \pm 6,9, \mathrm{~S} 2: 19,4 \pm 7,2$ and $\mathrm{S} 3: 19,5 \pm 7,5$ while for $\mathrm{Z}$ group, $7,3 \pm 10,7,15,7 \pm 4,8,17,3 \pm 5,5$, and $17,1 \pm 7,3$, respectively $(\mathrm{P}>.05)$. EX surface cleaning with $\mathrm{S} 3$ resulted in significantly higher SBS $(32,6 \pm 7,4)$ than $\mathrm{C}(17,4 \pm 8,9), \mathrm{S} 1(15,7 \pm 7,3)$ and S2 $(14,3 \pm 4,5)(\mathrm{P}<.05)$. Mainly adhesive failures were observed for $\mathrm{C}, \mathrm{S} 1$ and S2 groups while cohesive failures within cement were observed in S3. Conclusion: Cleaning paste application on saliva-contaminated lithium disilicate ceramic surface had a significant influence on resin-ceramic bond strength increase. 


\section{Introduction}

Cementation of all-ceramic restorations by adhesive luting resins have become a routine procedure for clinical use and problems in bonding of luting resins to ceramics have been solved significantly in recent years. The success of long-term resin bond to all-ceramic restorations have been well documented. ${ }^{1,2}$

Zirconium dioxide (zirconia) polycrystalline materials, also named as 'oxide ceramics' have been used in a wide range for single and/or multiunit fixed dental prostheses (FDPs) as well as implant abutments with their biocompatibility and relatively esthetic properties. ${ }^{3}$ Although, adhesive cementation is not a prerequisite for zirconia restorations ${ }^{1}$ it is recommended as in other all-ceramic materials, in terms of decreasing the risk of secondary caries development by sealing the impurities around the finish line and increasing the fracture resistance of the restored teeth and restorations. ${ }^{4}$ However, since zirconia does not contain a silicate phase, it cannot be adhesively luted as in silica-based all-ceramics. ${ }^{2}$ Silica-based all-ceramics, have the advantage of a successful bonding with self, light or dualcuring resin luting cements to prepared teeth provided that the luting surfaces of such restorations are etched with hydrofluoric acid followed by silanization. ${ }^{5}$ Generally accepted current protocol for adhesive cementation of zirconia restorations include airborne particle abrasion of the intaglio surfaces of the zirconia followed by application of phosphate-bondedmonomer-containing composite resins. ${ }^{6}$ However, air-abrasion might induce surface defects on zirconia reducing its strength ${ }^{7}$; and alternative luting surface conditioning methods such as selective infiltration etching, zirconia ceramic powder coating, ceramic pearl layer application, glaze layer application or recently introduced nano-structured alumina $\left(\mathrm{Al}_{2} \mathrm{O}_{3}\right)$ coating might be beneficial to overcome the problems occurring due to air-abrasion. ${ }^{8,9}$ Luting of zirconia restorations by conventional bis-GMA containing resin cements, which do not 
contain the bifunctional molecular monomer: 10-methacryloyloxydecyl dihydrogen phosphate (MDP), alone, have not been successful in establishing a durable long-term bond to oxide ceramics. ${ }^{9,10}$

In addition to the above mentioned difficulties in achieving a strong bond between the zirconia restoration and resin luting cements, the try-in procedure of an all-ceramic and/or zirconia restoration causes the intaglio bonding surface of the restoration to be generally contaminated with saliva, blood, or fitting indicator remnants such as silicone or try-in pastes, making the adhesive cementation of the zirconia restorations even more difficult. Failure in removal of the fluids or try-in materials results in reduction of the bond strength. ${ }^{9,11}$ Thus, any inorganic or organic contaminants should be eliminated before adhesive cementation. Mainly used methods of decontaminating the luting surfaces of ceramic/zirconia restorations are scrubbing the surface with acetone, application of 37\% phosphoric acid for 60 seconds once or for 30 seconds twice, cleaning with $96 \%$ ethanol for 15 seconds, $2 \%$ chlorhexidine or $5 \%$ sodium hypochlorite application or water spray. ${ }^{12}$ Recently, an alternative universal paste for extraoral cleaning of pre-treated ceramic and metal restoration surfaces which have been contaminated during intraoral try-in has been developed. ${ }^{13}$ This cleaning paste consists of an alkaline suspension of zirconium dioxide particles which are deemed to absorb the phosphate contaminants to bond to them than to the surface of the ceramic restoration leaving behind a clean zirconium dioxide surface. ${ }^{14,15}$

Therefore, the objective of this in vitro study was to evaluate the influence of various surface cleaning methods on shear bond strength (SBS) of three different all-ceramic surfaces after saliva contamination; thereby suggesting a preference of a purifying procedure for allceramic surfaces. The null hypothesis was that surface decontamination methods used for cleaning ceramic surfaces would not significantly differ in bond strengths according to the ceramic types. 


\section{Materials and Methods}

The chemical compositions of the materials used in the present study are listed in Table 1. Cubic specimens $(3 \times 3 \times 3 \mathrm{~mm})(\mathrm{N}=30)$ from three types of ceramics (zirconia, leucite and lithium disilicate); namely ${ }^{\mathrm{IPS}}$ e.max ZirCAD (IvoclarVivadent, Schaan, Liechtenstein) (Z), ${ }^{\text {IPS }}$ Empress CAD (IvoclarVivadent, Schaan, Liechtenstein) (E) and ${ }^{\text {IPS }}$ e.max CAD (IvoclarVivadent, Schaan, Liechtenstein) (EX) (n=10/subgroup) were prepared in a presintered form under water cooling by using a slow speed diamond saw (Isomet ${ }^{\circledR}$ 1000, Buehler, USA) (Fig. 1). All specimens were then sintered in ceramic and zirconia sintering furnaces according to the manufacturers' firing instructions (Fig. 2 a,b). A total of 120 cylindirical specimens with a diameter of $1 \mathrm{~mm}$ and $3 \mathrm{~mm}$ height were obtained from a composite resin (TetricCeram, IvoclarVivadent, Schaan, Liechtenstein) (Fig. 2c). Subsequently, ceramic and composite resin specimens were ultrasonically cleaned in ethanol series and deionized water for $15 \mathrm{~min}$, respectively. Surfaces of all specimens were wetpolished with 800-grit silicon carbide paper. Airborne-particle-abrasion with $50 \mu \mathrm{m} \mathrm{Al}_{2} \mathrm{O}_{3}$ at 2.5 bar pressure for $15 \mathrm{sec}$. from a distance of $10 \mathrm{~mm}$ was applied to the zirconia $(\mathrm{Z})$ specimens. ${ }^{14,16}$ Glass-ceramic specimens were etched with a $9 \%$ hydrofluoric acid (Ultradent Porcelain etch, Ultradent Products Inc.,USA) for $60 \mathrm{sec}$ and $20 \mathrm{sec}$ for leucite (E) and lithium disilicate (EX) glass-ceramics, respectively.

Three surfaces of cubic ceramic specimens were contaminated with fresh human saliva obtained from a healthy female donor who had not consumed any food or drinks 1.5 hrs before sample collection ${ }^{16}$ and 1 surface was used as control. For each specimen, surface 1(S1) was contaminated with saliva and cleaned with water spray. Surface 2 (S2) was cleaned with a $0.5 \%$ sodium hypochlorite solution and surface $3(\mathrm{~S} 3)$ was cleaned with a cleaning paste (Ivoclean ${ }^{\mathrm{TM}}$,IvoclarVivadent) after saliva contamination. Control surface (C) was not 
contaminated or cleaned. Composite cylinders were bonded to each silanated (Monobond Plus, IvoclarVivadent) ceramic surface with a resin luting cement (Variolink II, IvoclarVivadent). All luted specimen assemblies (Fig. 3) were stored at $37^{\circ} \mathrm{C}$ in deionized water until fracture. Shear bond strength tests were performed in a universal testing machine (Shimadzu, Japan) at a cross-head speed of $0,5 \mathrm{~mm} / \mathrm{min}$. The obtained results $(\mathrm{MPa} \pm \mathrm{SD})$ were statistically analyzed by a one-way ANOVA and Bonferroni correction at a significance level of 0.05 (SPSS 16.0 for Windows, Chicago, IL, USA).

\section{Scanning Electron Microscopy}

Representative fractured surfaces from each group were dried by vacuum dessication and carbon coated. A scanning electron microscope operating at $20 \mathrm{kV}$ (JSM-5200, JEOL, Tokyo, Japan) was used to observe the failure modes of the debonded ceramic specimens after SBS testing. Failure modes were classified either as adhesive failure at the ceramic surface or cohesive failure in the luting resin or in the composite resin. Failure areas of each mode were calculated and expressed as a percentage of the total bonding surface area for each test group (adhesive: $>75 \%$ : between resin and ceramic; cohesive: $>75 \%$ within resin and ceramic).

\section{Results}

Mean SBS values for E ceramic group were observed as C:14,9 $46, \mathrm{~S} 1: 12,1 \pm 6,9$, $\mathrm{S} 2: 19,4 \pm 7,2$ and $\mathrm{S} 3: 19,5 \pm 7,5$ while for $\mathrm{Z}$ group, $7,3 \pm 10,7,15,7 \pm 4,8,17,3 \pm 5,5$, and $17,1 \pm 7,3$, respectively $(\mathrm{P}>.05)$. EX ceramic surface cleaning with $\mathrm{S} 3$ regimen resulted in significantly 
higher SBS values $(32,6 \pm 7,4)$ than $\mathrm{C}(17,4 \pm 8,9), \mathrm{S} 1(15,7 \pm 7,3)$ and $\mathrm{S} 2(14,3 \pm 4,5)(\mathrm{P}<.05)$

(Fig. 4). Mainly adhesive failures were observed for C, S1, S2 and S3 groups for all ceramic groups. However some cohesive failures within the luting resin were observed in E and EX groups while no cohesive failures were seen in zirconia groups for C, S1, S2 and S3 surface treatments (Table 2). Universal cleaning paste resulted in a clean surface for glass-ceramic groups, and relatively zirconia group (Figs. 5-7).

\section{Discussion}

The performance of different ceramic surface cleaning methods with leucite, lithium disilicate and zirconia specimens after human salivary contamination has been investigated in the present study. The shear bond strength tests have revealed that lithium disilicate ceramic surface cleaned with the universal cleaning paste resulted in the highest SBS values and SEM images exhibited no visible contaminated areas on the ceramic surface.

Saliva consists of organic materials such as salivary proteins, bacteria and food debris in water solution. Salivary protein adsorption would occur not only on the tooth surface, but also on the restorative materials when the restorations are exposed to saliva or oral fluids. ${ }^{4}$ Surface cleansing, roughening with hydrofluoric acid, and activating the bonding surface are essential factors before cementation for achieving a strong and durable resin bond to the intaglio surface of the ceramic restoration. ${ }^{1}$ Scanning electron microscopy images of the present study indicated that cleaning with a $0.5 \%$ hypochlorite solution and universal cleaning paste proved to be more effective for the removal of saliva remnants while water rinsing alone was not sufficient. A possible explanation for the decreased SBS and increased adhesive failure could be that an invisible thin residual organic film might have covered the 
fitting surfaces of the restoration blocking the penetration of the silane and luting cement into the microporosities.

The success of adhesion involves both the restoration and the prepared tooth surface conditioning. Therefore, precautions should be taken not only for the restorative material surface cleaning, but for the tooth surface, too. Adhesion promotion to prepared tooth surfaces is not a concern for silica-based all-ceramic materials today with the use of light or dual-curing luting resin cements, glass-ionomer cements or self-adhesive resin cements after hydrofluoric acid etching and silanization of the cementation surfaces of the ceramic restorations. ${ }^{5}$ However, zirconia based restorations still present adhesive luting problems since yttrium oxide stabilized zirconia contains less than $2 \%$ aluminium oxide and silicone oxide phases, which are necessary for etchability of the luting surface of a zirconia restoration. ${ }^{17}$ Although strategies for adhesive luting of zirconia restorations to prepared teeth such as airborne-particle-abrasion with $50 \mu \mathrm{m} \quad \mathrm{Al}_{2} \mathrm{O}_{3}$ at 2.5 bar followed by application of MDP-containing composite resins have been developed ${ }^{1}$ and have presented durable bond strengths even after water storage and repeated thermal cycling, ${ }^{18,19}$ the long-term bond to zirconia ceramic with an MDP-containing resin cement (Panavia F 2.0) was found to be unstable after application of different cleaning methods simulation for clinical conditions like saliva and silicone check-fit impression material contamination. ${ }^{16}$

Since the problem of adhesive luting of zirconia is still a concern and contamination of the intaglio surface of this type of restoration and effective elimination of the surface contaminants might increase the risk of adhesion failure, removal of contaminants is of vital importance. In a previous study where the effect of contaminations (saliva and disclosing agent) and cleaning methods on bonding of zirconia ceramic have been investigated by using X-ray photoelectron spectroscopic (XPS) chemical analysis and tensile strength testing; 
contamination was reported to significantly decrease the bond strength of zirconia and airborne-particle-abrasion was the most effective cleaning method. ${ }^{20}$

Although standard airborne-particle-abrasion was not used as a ceramic decontamination method in the present study; all ceramic surfaces were air-abraded with $50 \mu \mathrm{m} \mathrm{Al}_{2} \mathrm{O}_{3}$ at 2.5 bar pressure, simulating the as arrived restoration from the laboratory to the clinic and the contamination was then conducted mimicking the final intraoral try-in of the restoration before cementation and the most practical and commonly used decontamination methods were then applied. As has been previously reported; airborneparticle abrasion produces surface roughness that is necessary for adhesive luting, but on the other hand, it might increase the possibility of contamination and prevent adequate decontamination because of the created pits and irregularities on the luting surfaces of the restorations. $^{20}$ The results obtained from the SEM images and SBS values present in vitro study confirmed these findings, also. On the other hand, a newly developed surface cleaning paste for metal or zirconia restorations have been investigated in the present study, and it was found to be most effective for lithium disilicate glass-ceramic group other than zirconia specimens. Therefore the null hypothesis stating that surface decontamination methods would not significantly affect the SBS of the ceramics used in the study was rejected.

The universal paste used in this study is an alkali suspension of zirconium dioxide particles in water and it has been reported to absorb the phosphate contaminants in the media leaving a clean surface. ${ }^{13}$ The contamination medium in the present study was only human saliva. Human saliva contains several proteins involved in preventing or promoting bacterial adhesion to oral soft and hard tissues. Proline-rich proteins (PRP) in the saliva are especially found in acquired enamel pellicle and act as strong promoters for bacterial adhesion with their molecular amino and carboxy terminals, controlling calcium phosphate and interaction with oral bacteria, respectively. ${ }^{21}$ Therefore, the above mentioned phosphate absorbing 
mechanism of the universal cleaning paste used in the present study might not have affected on the removal of PRPs in the saliva, thereby might have blocked the removal of these proteins from the air-abraded and saliva contaminated zirconia surface leaving behind a possible film layer decreasing the bond strength values.

The universal cleaning paste was more effective for the lithium disilicate surface cleaning, also supported with SBS test findings. Lithium disilicate ceramics contain quartz, lithium dioxide, phosphor oxide, alumina, potassium oxide, and other components and IPS e.max CAD has a two-crystalline phase (metasilicate and fully crystallized lithium disilicate forms) microstructure $\left(\mathrm{Li}_{2} \mathrm{Si}_{2} \mathrm{O}_{5}\right){ }^{22}$ When the glass-ceramics are etched with hydrofluoric acid, a chemical reaction: $4 \mathrm{HF}+\mathrm{SiO}_{2} \rightarrow \mathrm{SiF}_{4}+2 \mathrm{H}_{2} \mathrm{O}$ occurs since the affinity of fluoride to silicon is higher than to oxygen. ${ }^{23}$ With the application of the universal cleaning paste on the lithium disilicate followed by HF acid etching in the present study; the phosphor oxide $\left(\mathrm{P}_{2} \mathrm{O}_{5}\right)$ might have reacted with dissolved silica matrix to yield phosphate groups and the phosphate absorbing ability of the universal cleaning paste might have eliminated all the phosphate contaminants on the glass-ceramic surface. This finding was supported by obtained SEM images, also revealing a clean surface (Fig. 6).

It has also been demonstrated through XPS analysis that any organic coating composed of $\mathrm{C}, \mathrm{O}$, and $\mathrm{Si}$ on the ceramic surface led to a significant reduction in ceramic bond strength after saliva immersion and the application of silicone disclosing agent for try-in purposes. ${ }^{20}$ XPS analysis has been reported to be over surface sensitive with an examination of the outermost 2-10 $\mathrm{nm}$ layer of the specimens ${ }^{24}$ and the subsurface (ceramic) could still be observed. One limitation of the present study was that a chemical analysis, such as XPS was not used in the present study to observe to what extent the contamination reached on the irregularities and contaminated ceramic surfaces and the amount of the removal of the contaminant. The main objective rather focused on the effectiveness on the newly developed 
universal cleaning paste in terms of bond strength and electron microscopic observation of any contaminant presence on the ceramic surfaces.

Further studies on the cleaning effectiveness of the most commonly preferred surface decontaminants on conditioned real ceramic restorations ready for adhesive cementation, but intraorally tried for final control should be conducted, although standardization of contaminants are difficult for clinical studies and production of duplicate ceramic restorations may not be practical and economical. 


\section{Conclusions}

Cleaning paste application on lithium disilicate saliva-contaminated ceramic surface had a significant influence on resin-ceramic bond strength increase.

\section{Clinical Relevance}

Adhesive cementation of zirconia presents a clinically challenging protocol and the cementation surface contamination of the zirconia restorations and the inadequate removal of the contaminants even increase the risk of failure, as for all ceramic types. This study demonstrated that conventional hypochlorite solution and extraoral universal cleaning paste applications resulted in effective removal of human saliva on the luting surfaces of tested ceramic materials; thus can be recommended for routine clinical cleaning procedures before the cementation process.

\section{Acknowledgement}

The authors of the study would like to thank Prof. Dr. Tijen Pamir from Restorative Dentistry Department, Ege University, School of Dentistry for conducting the shear bond strength tests and Prof. Dr. Bilge Hakan Şen from Endodontics Department, Ege University, School of Dentistry for scanning electron microscopy analyses. 


\section{References:}

1. Blatz MB, Sadan A, Kern M. Resin-ceramic bonding: a review of the literature. J Prosthet Dent 2003;89:268-74.

2. Thompson J, Stoner B, Piascik J, and Smith R. Adhesion/cementation to zirconia and other non-silicate ceramics: Where are we now? Dent Mater, 2011; 27(1):7182.

3. Denry I, Kelly JR. State of the art of zirconia for dental applications. Dent Mater 2008; 24:299-307.

4. Yang B, Wolfart S, Scharnberg M, Ludwig K, Adelung R, Kern M. Influence of contamination on zirconia ceramic bonding. J Dent Res 2007;86:749-53.

5. Özcan M, Dündar M, Çömlekoğlu ME. Adhesion concepts in dentistry: tooth and material aspects. J Adhes Scie and Technol 2012;0(online article first):1-21.

6. Amaral R, Özcan M, Valandro LF, Balducci I, and Bottino MA. Effect of conditioning methods on the microtensile bond strength of phosphate monomerbased cement on zirconia ceramic in dry and aged conditions. J Biomed Mater Res B Appl Biomater, 2008;85:1-9.

7. Zhang Y, Lawn BR, Malament KA, Van Thompson P, Rekow ED. Damage accumulation and fatigue life of particle-abraded ceramics. Int $\mathrm{J}$ Prosthodont $2006 ; 19: 442-8$.

8. Cura C, Özcan M, Isik G, Saracoglu A. Comparison of alternative adhesive cementation concepts for zirconia ceramic: glaze layer vs zirconia primer. J Adhes Dent 2012;14:75-82.

9. Zhang S, Kocjan A, Lehmann F, Kosmac $`$ T, Kern M. Influence of contamination on resin bond strength to nano-structured alumina-coated zirconia ceramic. Eur J Oral Sci 2010; 118: 396-403. 
10. Piwowarczyk A, Lauer HC, Sorensen JA. In vitro shear bond strength of cementing agents to fixed prosthodontic restorative materials. J Prosthet Dent 2004;92: 265-73.

11. Eiriksson SO, Pereira PN, Swift EJ Jr, Heymann HO, Sigurdsson A. Effects of saliva contamination on resin-resin bond strength. Dent Mater 2004;20:37-44.

12. Aboush YE. Removing saliva contamination from porcelain veneers before bonding.J Prosthet Dent 1998;80:649-53.

13. Scientific Documentation Ivoclean, IvoclarVivadent 2011;3-10.

14. Klosa K, Wolfart S, Lehmann F, Wenz HJ, Kern M. The effect of storage conditions, contamination modes and cleaning procedures on the resin bond strength to lithium disilicate ceramic. J Adhes Dent 2009;11:127-35.

15. Yang B, Lange-Jansen HC, Scharnberg M, Wolfart S, Ludwig K, Adelung R, Kern M. Influence of saliva contamination on zirconia ceramic bonding; Dent Mater 2008; 24:508-13.

16. Quaas AC, B. Yang B, M. Kern. Panavia F 2.0 bonding to contaminated zirconia ceramic after different cleaning procedures. Dent Mater 2007;23:506-12.

17. Pilathadka S, Vahalová D, Vosáhlo T. The Zirconia: a new dental ceramic material. an overview. Prague Medical Report 2007;108:5-12.

18. Wegner SM, Kern M. Long-term resin bond strength to zirconia ceramic. J Adhes Dent 2000;2:139-47.

19. Wegner SM, Gerdes W, Kern M. Effect of different artificial aging conditions on ceramic-composite bond strength. Int J Prosthodont 2002;15:267-72.

20. Yang B, Scharnberg M, Wolfart S, Anne C. Quaas AC,Ludwig K, Adelung R, Kern M. Influence of contamination on bonding to zirconia ceramic. J Biomed Mater Res Part B 2007: Appl Biomater 81B: 283-90. 
21. Schenkels LC, Veerman EC, Nieuw Amerongen AV. Biochemical composition of human saliva in relation to other mucosal fluids. Crit Rev Oral Biol Med 1995;6:161-75.

22. Anusavice K. Phillips' Science of Dental Materials. Eleventh Edition. W. B. Saunders Company Philadelphia; 2003.

23. Cömlekoğlu ME, Dündar M, Güngör MA, Sen BH, Artunç C.Preliminary evaluation of titanium tetrafluoride as an alternative ceramic etchant to hydrofluoric acid. J Adhes Dent 2009;11:447-53.

24. Moulder JF, Stickle WF, Sobol PE, Bomben KD. Handbook of X-ray Photoelectron Spectroscropy. Minnesota: Perkin-Elmer;1992. 


\section{Legends}

Table 1. The chemical compositions of the materials used in the study.

Table 2. Failure types per test group. Adhesive failure at the interface between the ceramic and luting resin $(\mathrm{A})$; cohesive failure within the resin only $(\mathrm{C})$.

Fig. 1. Ceramic specimens cut under water cooling in their presintered forms.

Fig. 2. Sintered zirconia (a) and all-ceramic (b) cubic specimens; cylindirical composite resin specimens (c).

Fig. 3. Luted ceramic and composite resin assemblies (a) and custom made specimen holder for SBS tests (b).

Fig. 4. Box plot graphic of mean SBS values of the ceramic groups according to surface treatment regimens.

Fig. 5. Scanning electron microscopic images of the surface treatments of the leucite allceramic group. The arrows indicate the contaminated spots.

Fig. 6. Scanning electron microscopic images of the surface treatments of the lithium disilicate all-ceramic group. The arrows indicate the contaminated areas appearing as white spots. Note the decreased amount of contaminated areas in the universal cleaning paste group.

Fig. 7. Scanning electron microscopic images of the surface treatments of the zirconia group. The arrows indicate the contaminated areas appearing as white spots. 


\begin{tabular}{|c|c|c|c|}
\hline Product & Type & $\begin{array}{l}\text { Chemical } \\
\text { composition }\end{array}$ & Manufacturer \\
\hline $\begin{array}{l}\text { IPS e.max } \\
\text { ZirCAD }\end{array}$ & $\begin{array}{ll}\text { zirconium } & \text { dioxide } \\
\text { framework } & \end{array}$ & $\begin{array}{l}87-95 \% \mathrm{ZrO}_{2} \text { (wt) } \\
4-6 \% \mathrm{Y}_{2} \mathrm{O}_{3} \\
1-5 \% \mathrm{HfO}_{2} \\
0-1 \% \mathrm{Al}_{2} \mathrm{O}_{3} \\
<0.2 \% \text { other oxides }\end{array}$ & $\begin{array}{l}\text { IvoclarVivadent } \\
\text { Schaan, Liechtenstein }\end{array}$ \\
\hline $\begin{array}{l}\text { IPS e.max } \\
\text { CAD }\end{array}$ & $\begin{array}{lr}\text { lithium } & \text { disilicate } \\
\text { veneering } & \text { ceramic } \\
\text { block } & \end{array}$ & $\begin{array}{l}57-80 \% \mathrm{SiO}_{2} \\
11-19 \% \mathrm{Li}_{2} \mathrm{O} \\
0-13 \% \mathrm{~K}_{2} \mathrm{O} \\
0-11 \% \mathrm{P}_{2} \mathrm{O}_{5} \\
0-8 \% \mathrm{ZrO}_{2} \\
0-5 \% \mathrm{Al}_{2} \mathrm{O}_{3} \\
0-5 \% \mathrm{MgO} \\
0-8 \% \text { colouring oxides }\end{array}$ & $\begin{array}{l}\text { IvoclarVivadent } \\
\text { Schaan, Liechtenstein }\end{array}$ \\
\hline $\begin{array}{l}\text { IPS Empress } \\
\text { CAD }\end{array}$ & $\begin{array}{l}\text { leucite } \\
\text { glass-ceramic block }\end{array}$ & $\begin{array}{l}60-65 \% \mathrm{SiO}_{2} \\
16-20 \% \mathrm{Al}_{2} \mathrm{O}_{3} \\
10-14 \% \mathrm{~K}_{2} \mathrm{O} \\
\text { 3.5-6.5\% } \mathrm{Na}_{2} \mathrm{O} \\
\text { 0.5-7\% other oxides } \\
\text { 0.2-1\% pigments }\end{array}$ & $\begin{array}{l}\text { IvoclarVivadent } \\
\text { Schaan, Liechtenstein }\end{array}$ \\
\hline MonoBond Plus & $\begin{array}{l}\text { Universal } \\
\text { primer mediating a } \\
\text { bond between metal, } \\
\text { glass/oxide ceramics } \\
\text { and resin }\end{array}$ & $\begin{array}{l}50-100 \% \text { ethanol } \\
<2.5 \% \\
3- \\
\text { trimethoxysilylpropyl } \\
\text { methacrylate } \\
<2.5 \% \text { methacrylated } \\
\text { phosphoric acid ester }\end{array}$ & $\begin{array}{l}\text { IvoclarVivadent } \\
\text { Schaan, Liechtenstein }\end{array}$ \\
\hline $\begin{array}{l}\text { Variolink II } \\
\text { Heliobond }\end{array}$ & $\begin{array}{l}\text { Dual-curing } \\
\text { resin cement }\end{array}$ & $\begin{array}{l}\text { Bis-GMA, triethylene } \\
\text { glycoldimethacrylate, } \\
\text { initiators, stabilizers }\end{array}$ & $\begin{array}{l}\text { IvoclarVivadent } \\
\text { Schaan, Liechtenstein }\end{array}$ \\
\hline $\begin{array}{l}\text { Paste A } \\
\text { Paste B }\end{array}$ & & $\begin{array}{l}\text { Bis-GMA, urethane } \\
\text { dimethacrylate, } \\
\text { TEGDMA, inorganic } \\
\text { filler, ytterbium } \\
\text { trifluoride, initiator, } \\
\text { stabilizer; } \\
\text { Bis-GMA, } \\
\text { urethane } \\
\text { dimethacrylate, } \\
\text { TEGDMA, inorganic } \\
\text { filler, ytterbium } \\
\text { trifluoride, benzoyl } \\
\text { peroxide, stabilizer }\end{array}$ & \\
\hline TetricCeram & Composite resin & $\begin{array}{l}2.5-10 \% \text { bis-GMA } \\
2.5-10 \% \text { urethane } \\
\text { dimethacrylate } \\
2.5-10 \% \\
\text { decamethylene } \\
\text { dimethacrylate }\end{array}$ & $\begin{array}{l}\text { IvoclarVivadent } \\
\text { Schaan, Liechtenstein }\end{array}$ \\
\hline
\end{tabular}

Table 1 The chemical compositions of the materials used in the study. 


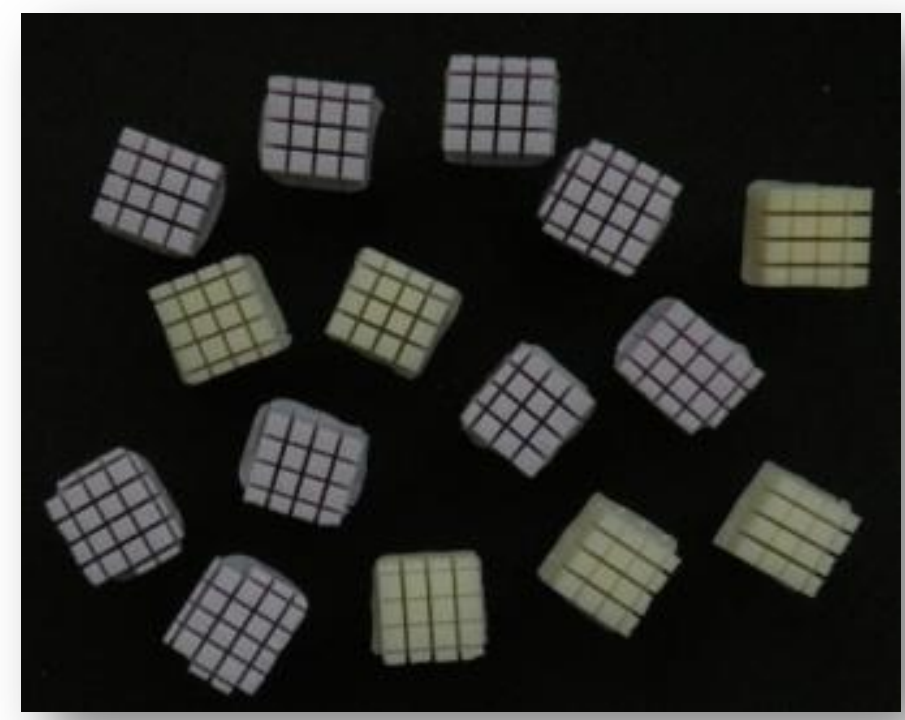

Figure 1 Ceramic specimens cut under water cooling in their presintered forms.
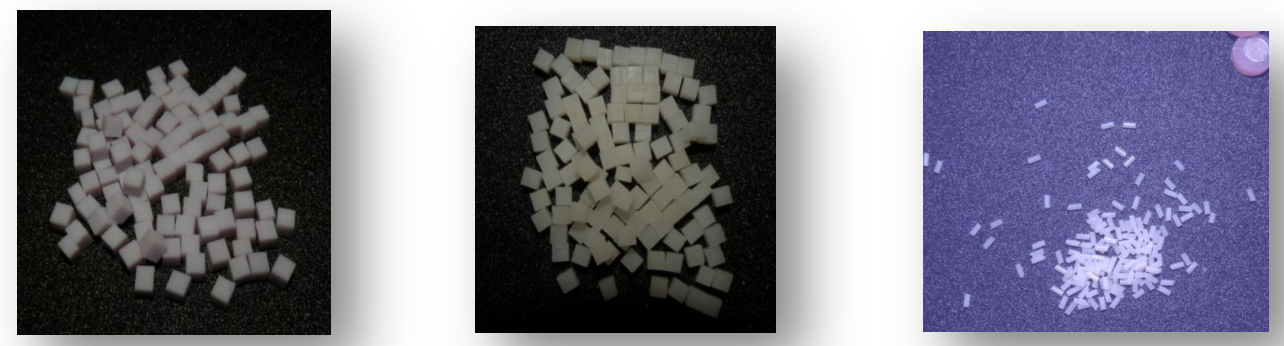

Figure 2 Sintered zirconia (a) and all-ceramic (b) cubic specimens; cylindirical composite resin specimens (c). 

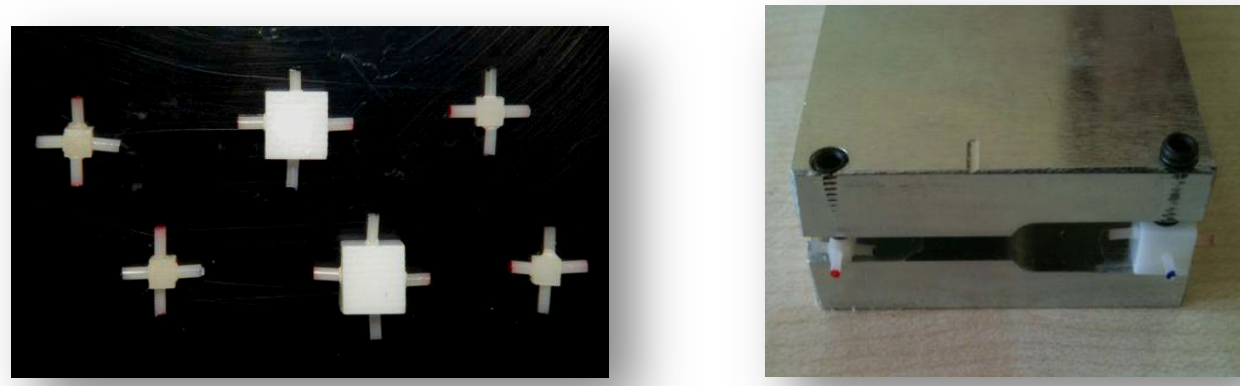

Figure 3 Luted ceramic and composite resin assemblies (a) and custom made specimen holder for SBS tests (b).

ceramic material

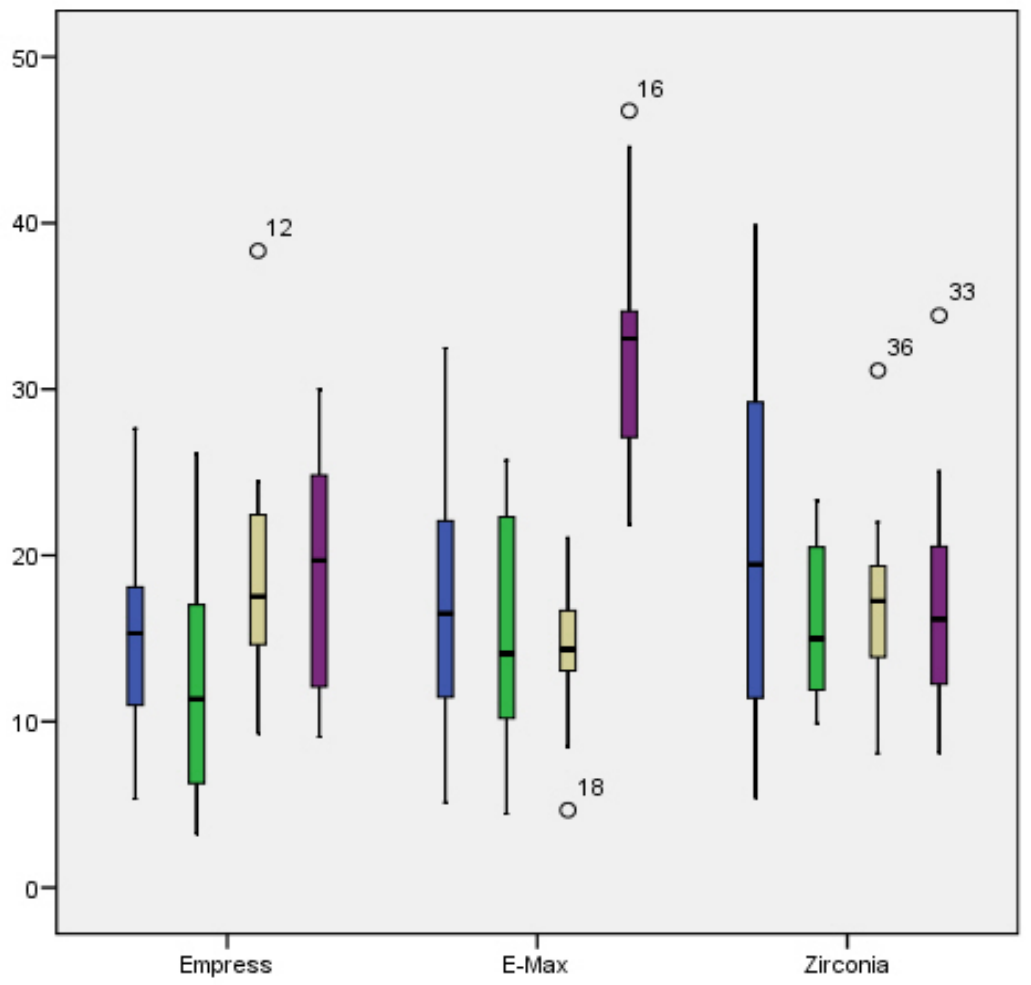

$\frac{\square}{\square}$

Figure 4 Box plot graphic of mean SBS values of the ceramic groups according to surface treatment regimens. 


\begin{tabular}{|c|c|c|c|c|c|c|c|c|}
\hline & \multicolumn{2}{|c|}{$\begin{array}{c}\text { saliva+hypochloride } \\
\text { (NaOCl) }\end{array}$} & \multicolumn{2}{|c|}{ saliva+water } & \multicolumn{2}{c|}{$\begin{array}{c}\text { universal cleaning } \\
\text { paste }\end{array}$} & \multicolumn{2}{c|}{ control } \\
\hline & A & C & A & C & A & C & A & C \\
\hline $\begin{array}{c}\text { Empress CAD } \\
\text { (N:13) }\end{array}$ & 11 & 2 & 13 & 0 & 11 & 2 & 13 & 0 \\
\hline $\begin{array}{c}\text { e.max CAD } \\
\text { (N:12) }\end{array}$ & 10 & 2 & 12 & 0 & 8 & 4 & 11 & 1 \\
\hline Zirconia (N:14) & 14 & 0 & 14 & 0 & 14 & 0 & 14 & 0 \\
\hline
\end{tabular}

Table 2 Failure types per test group. Adhesive failure at the interface between the ceramic and luting resin (A); cohesive failure within the resin only (C).

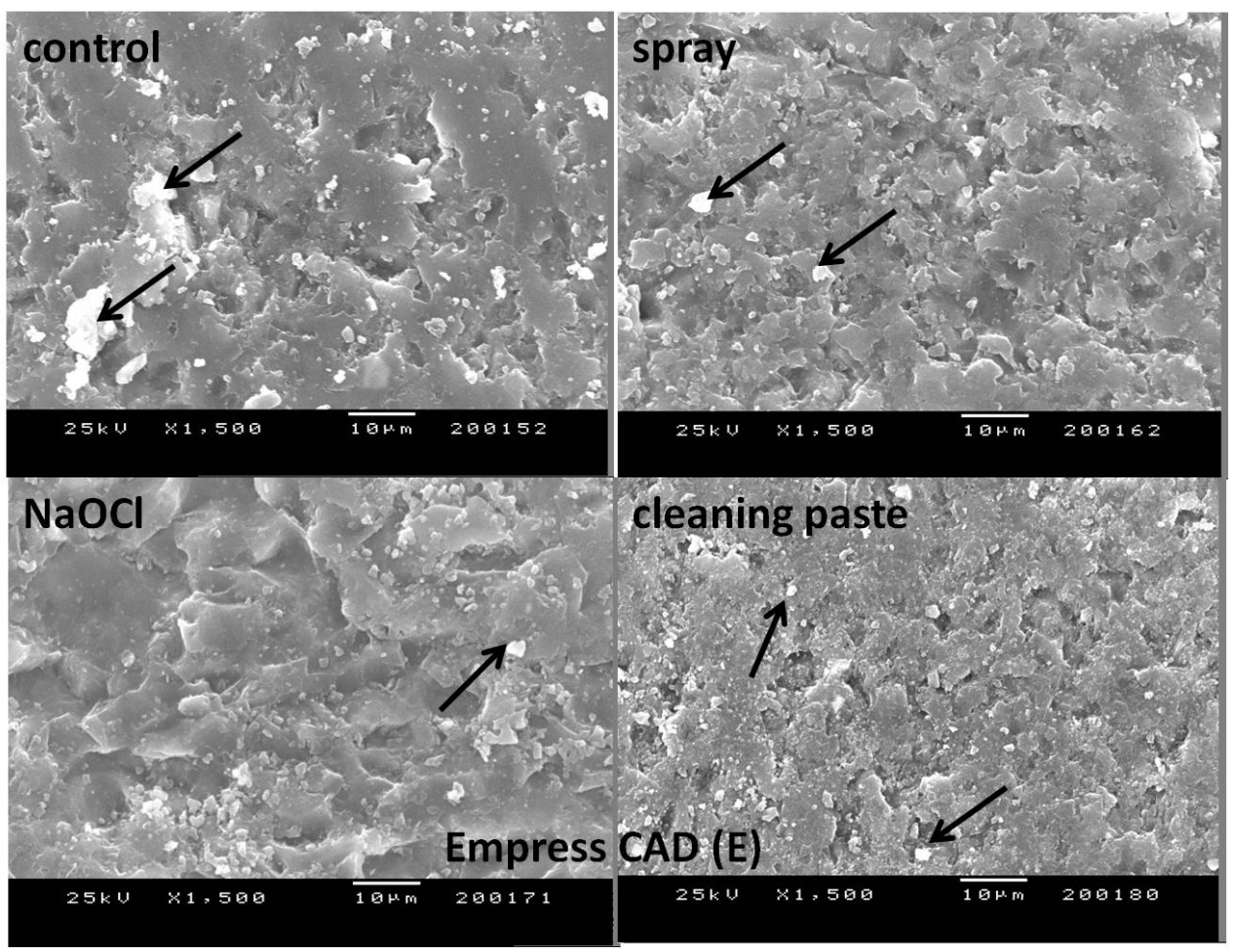

Figure 5 Scanning electron microscopic images of the surface treatments of the leucite all-ceramic group. The arrows indicate the contaminated spots. 


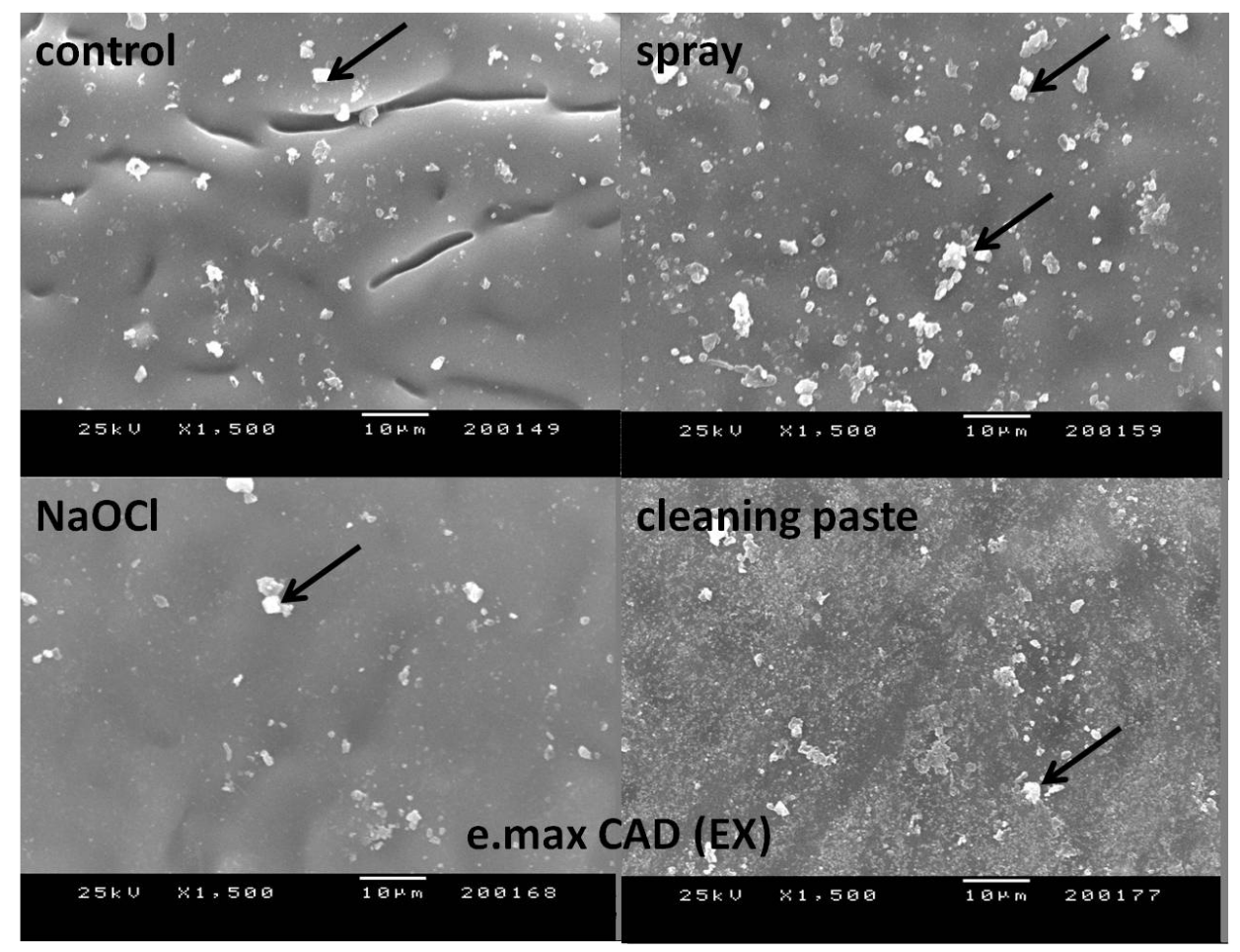

Figure 6 Scanning electron microscopic images of the surface treatments of the lithium disilicate all-ceramic group. The arrows indicate the contaminated areas appearing as white spots. Note the decreased amount of contaminated areas in the universal cleaning paste group. 


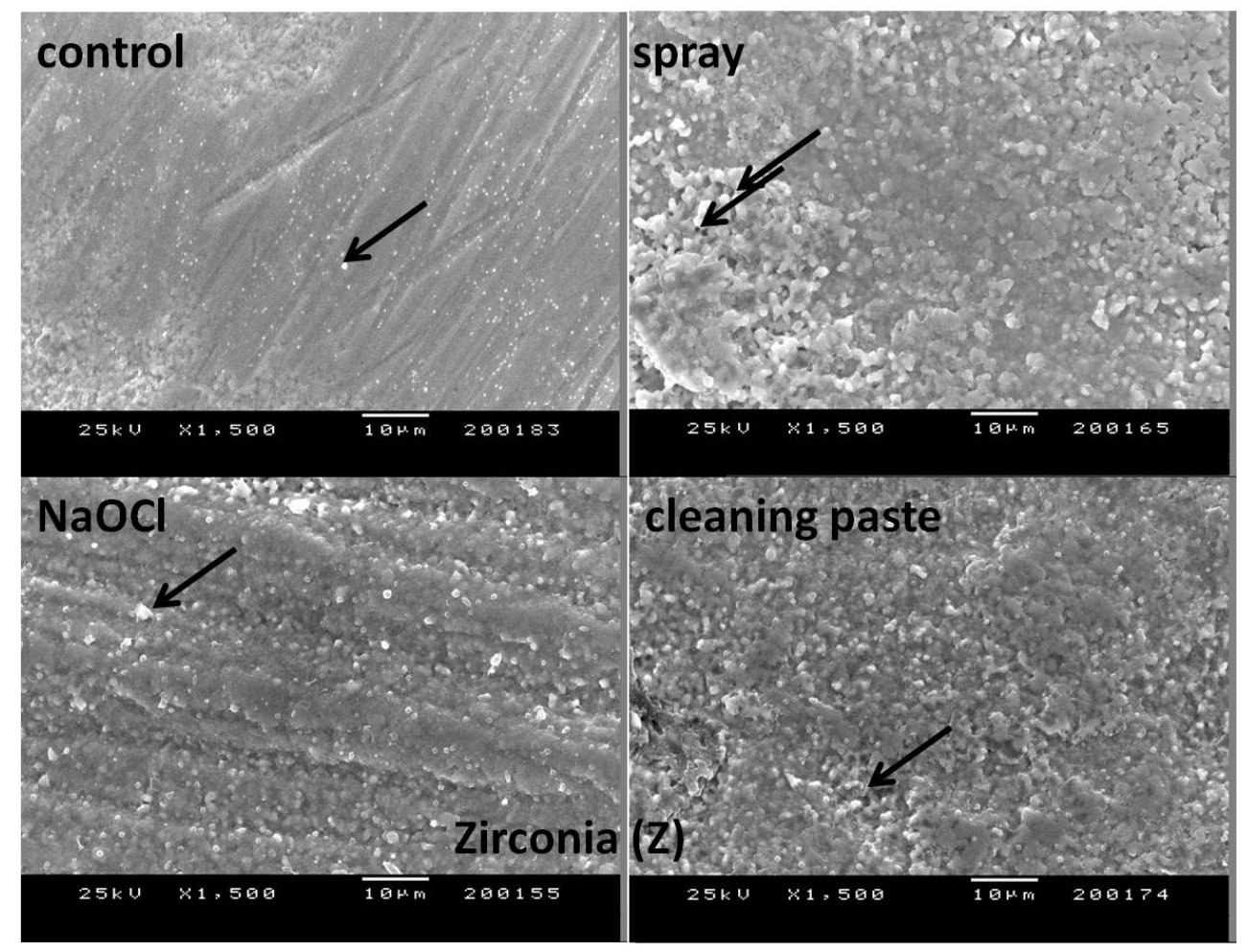

Figure 7 Scanning electron microscopic images of the surface treatments of the zirconia group. The arrows indicate the contaminated areas appearing as white spots. 